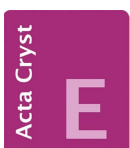

CRYSTALLOGRAPHIC COMMUNICATIONS

ISSN 2056-9890

Received 27 January 2021

Accepted 2 February 2021

Edited by W. T. A. Harrison, University of Aberdeen, Scotland

Keywords: octahydroacridine; Povarov reaction; Hirshfeld surface; energy frameworks; DFT calculations; spectroscopic characterization; crystal structure.

CCDC reference: 2004267

Supporting information: this article has supporting information at journals.iucr.org/e

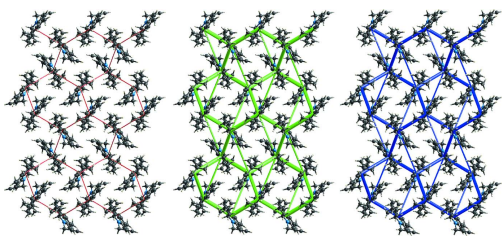

\section{Synthesis, crystal structure, Hirshfeld surface analysis and energy framework calculations of trans-3,7,9,9-tetramethyl-10-(prop-2-yn-1-yl)- 1,2,3,4,4a,9,9a,10-octahydroacridine}

\author{
Mauricio Acelas, ${ }^{a}$ Analio Dugarte-Dugarte, ${ }^{b}$ Arnold R. Romero Bohórquez, \\ José Antonio Henao, ${ }^{\mathrm{c}}$ José Miguel Delgado ${ }^{\mathrm{b}}$ and Graciela Díaz de Delgado ${ }^{\mathrm{b}}$ *
}

\begin{abstract}
${ }^{a}$ Grupo de Investigación en Compuestos Orgánicos de Interés Medicinal (CODEIM), Parque Tecnológico Guatiguará, Universidad Industrial de Santander, Piedecuesta, Colombia, 'b Laboratorio de Cristalografía-LNDRX, Departamento de Química, Facultad de Ciencias, Universidad de los Andes, Mérida, Venezuela, and ${ }^{\mathbf{c}}$ Grupo de Investigación en Química Estructural (GIQUE), Escuela de Química, Facultad de Ciencias, Universidad Industrial de Santander, Bucaramanga, Colombia. *Correspondence e-mail: gdiazdedelgado@gmail.com
\end{abstract}

The title heterocyclic compound, $\mathrm{C}_{20} \mathrm{H}_{27} \mathrm{~N}$, has been prepared in good yield (72\%) via a $\mathrm{BiCl}_{3}$-catalyzed cationic Povarov reaction between $\mathrm{N}$-propargyl-4methylaniline and $( \pm)$-citronellal. The $\mathrm{X}$-ray single-crystal study indicates that the structure consists of molecules connected by $\mathrm{C}-\mathrm{H} \cdots \pi$ contacts to produce chains, which pack in a sandwich-herringbone fashion along the $b$-axis direction. Hirshfeld surface analysis indicates that $\mathrm{H} \cdots \mathrm{H}$ interactions dominate by contributing $79.1 \%$ to the total surface. Energy frameworks and DFT calculations indicate a major contribution of dispersive forces to the total interaction energy.

\section{Chemical context}

The octahydroacridine (OHA) scaffold is a synthetic nitrogen heterocycle of significant importance in the fields of organic and medicinal chemistry. Its biological and pharmacological potential applications have been demonstrated over past decades (Ermolaeva et al., 1968; Del Giudice et al., 1997; Ulus et al., 2016). The assembly of the OHA motif has been achieved by synthetic routes involving classic Beckman rearrangement (Sakane et al., 1983), intramolecular Friedel-Crafts acid-mediated cyclization (Kouznetsov et al., 2000) and multicomponent aminocyclization reactions (Selvaraj \& Assiri, 2019). Noticeably, other approaches such as the organocatalytic aza-Michael/aldol (Li et al., 2018) and the Povarov reactions (Wu \& Wang, 2014) have emerged as powerful tactics to control stereochemical features around the OHA core involving, for example, the selective insertion of multiple stereocenters. Moreover, the cationic version of the above mentioned Povarov reaction can be used to exploit natural sources of chemicals, demonstrating that citronellal, the major component of citronella essential oil, provides an expedite and diastereoselective alternative towards $N$-substituted OHAs (Acelas et al., 2017).

The direct $N$-insertion of reactive groups, such as the propargyl fragment, via cationic Povarov reaction, enables access to multiple molecular hybrids. This rational and relevant synthetic strategy prompts advantages such as broadening the pharmacological spectrum of several heterocycles and the enhancement in the therapeutic potential for specific 
diseases (Müller-Schiffmann et al., 2012; Güiza et al., 2019). Thus, some examples including OHA-isoxazole and OHA1,2,3-triazole molecular hybrids have already been described (Acelas et al., 2019).

Despite the potential applications as pharmacological models, only a few examples of OHA crystal structures have been reported. It must be mentioned that the structural features obtained from the crystallographic data have been of the utmost importance and have served to accurately describe the stereochemical preference of different OHA synthesis pathways (Li et al., 2018; Zaliznaya et al., 2016), illustrate molecular conformations (Fröhlich et al., 1994; Gan et al., 2000), and establish the effect of the reagent source (citronellal $v s$ citronella essential oil) in the OHA crystal structure obtained via cationic Povarov reaction (Acelas et al., 2020).

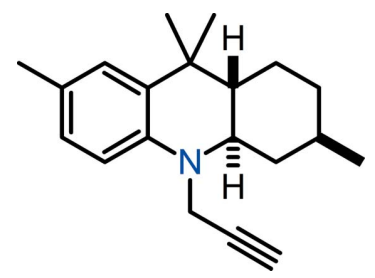

Herein, the synthesis, spectroscopic characterization, crystal structure and theoretical study of a new octahydroacridine, trans- $N$-propargyl-3,7,9,9-tetramethyl-1,2,3,4,4a,9,9a,10-octahydroacridine, $\mathrm{C}_{20} \mathrm{H}_{27} \mathrm{~N}$, are described.

\section{Structural commentary}

Fig. 1 shows the molecular structure of the title compound (3) with the atom- and ring-labeling scheme. The compound crystallizes with one molecule in the asymmetric unit in space group $P 2{ }_{1} 2_{1} 2_{1}$. The analysis of ring geometry parameters with PLATON (Spek, 2020) indicates that ring $A$ has a chair conformation. Atoms $\mathrm{N} 1$ and $\mathrm{C} 9$ are equatorial with respect to atoms $\mathrm{C} 5$ and $\mathrm{C} 6$, respectively. This leads to a trans configuration for the fusion of rings $A$ and $B$. The angle N1-C18$\mathrm{C} 19$ is $112.97(15)^{\circ}$, which can be correlated to the angle between the $\mathrm{N}-\mathrm{C} \equiv \mathrm{C}$ unit and the plane containing rings $B$ and $C$ (Fig. 1). A calculation carried out with Mercury (Macrae

Figure 1

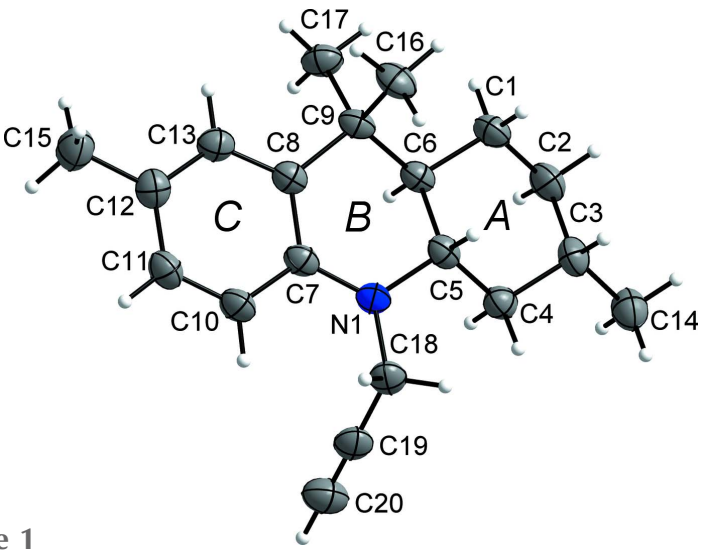

The molecular structure of $\mathbf{3}$ with the atom- and ring-labeling scheme. Ellipsoids are drawn at the $30 \%$ level of probability.

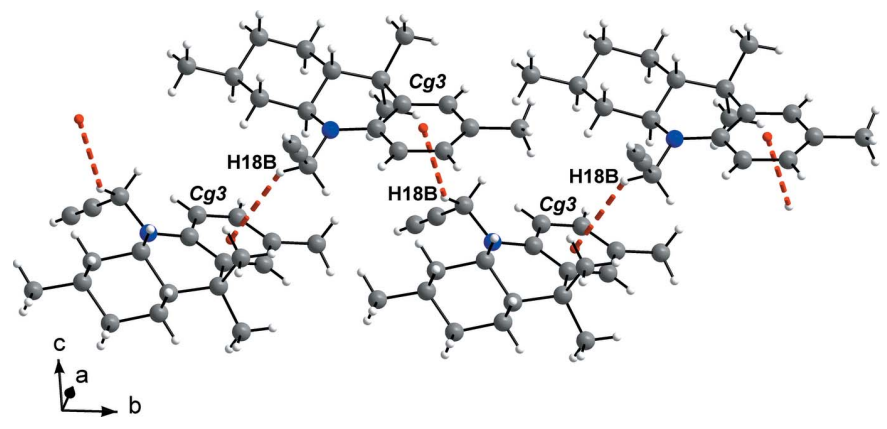

Figure 2

The packing of $\mathbf{3}$ showing chains of molecules connected by $\mathrm{C}-\mathrm{H} \cdots \pi$ interactions along the $b$-axis direction.

et al., 2020) for the related hydroquinoline structures discussed in the Database survey section below indicates this value ranges from 110.76 to $113.53^{\circ}$ with a mean value of $112.45^{\circ}$. The $\mathrm{C} \equiv \mathrm{C}$ bond length in compound $\mathbf{3}$ is 1.168 (3) $\AA$, in excellent agreement with the mean value observed in related structures $(1.169 \AA)$. The relative stereochemistries of atoms $\mathrm{C} 3, \mathrm{C} 5$ and $\mathrm{C} 6$ in the crystal studied are $S, S$ and $R$, respectively.

\section{Supramolecular features}

In the crystal, the molecules of $\mathbf{3}$ interact via $\mathrm{C}-\mathrm{H} \cdots \pi$ contacts between the $-\mathrm{CH}-\mathrm{C} \equiv \mathrm{C}$ grouping of a molecule and the centroid $(\mathrm{Cg} 3)$ of ring $C$ of a molecule related by symmetry operation (i) $\left[1-x, \frac{1}{2}+y, \frac{1}{2}-z\left(2_{1}\right.\right.$ screw axis along $b)]$ to form helical chains propagating along the $b$-axis direction (Fig. 2). The $\mathrm{H} \cdots C g 3$ distance is $2.98 \AA$ and the $\mathrm{C}-$ $\mathrm{H} \cdots \mathrm{Cg} 3$ angle is $146^{\circ}$. The chains form columns, which interact via weak $\mathrm{C}-\mathrm{H} \cdots \mathrm{C}$ contacts and van der Waals interactions. Some of these contacts are shown in Fig. 3. For

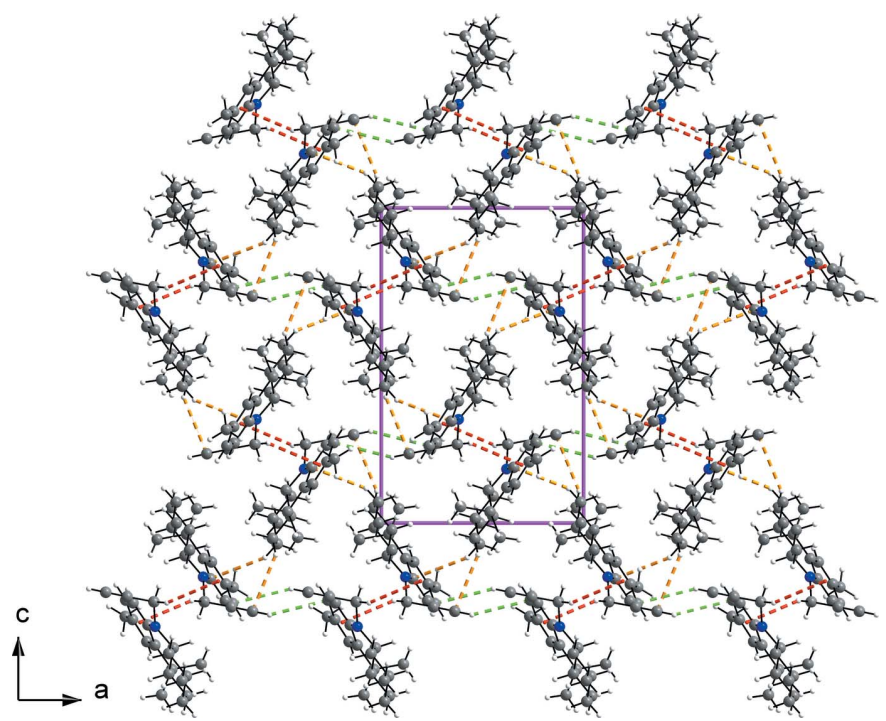

Figure 3

The packing arrangement viewed down [010]. Some short contacts are shown with dashed lines: $\mathrm{C}-\mathrm{H} \cdots C g 3$ in red and $\mathrm{C}-\mathrm{H} \cdots \mathrm{C}$ in orange and green. 
example, $\mathrm{C} 11 \cdots \mathrm{H} 20^{\mathrm{ii}}$ contacts $(3.00 \AA, \mathrm{C} 10-\mathrm{C} 11 \cdots \mathrm{H} 20=$ $104^{\circ}$, shown in green) link the columns along the $a$-axis direction. Additional interactions involving $\mathrm{C} 7$ and $\mathrm{C} 20$ (shown in orange) with atoms $\mathrm{H} 2 B$ and $\mathrm{H} 1 A$, respectively, of a molecule related by symmetry operation (iii) $\left(-\frac{1}{2}+x, \frac{3}{2}-y\right.$, $1-z$ ), connect the columns along the $c$-axis direction $\left(\mathrm{C} 7 \cdots \mathrm{H} 2 B=3.05 \AA, \mathrm{C} 8-\mathrm{C} 7 \cdots \mathrm{H} 2 B=100^{\circ} ; \mathrm{C} 20 \cdots \mathrm{H} 1 A=\right.$ $\left.3.03 \AA, \mathrm{C} 19-\mathrm{C} 20 \cdots \mathrm{H} 1 A=100^{\circ}\right)$. The columns pack in a basket-weave tiling fashion (Fig. 3), also described as a sandwich-herringbone motif (Loots \& Barbour, 2012).

\section{Hirshfeld surface analysis and energy framework calculations}

The $d_{\text {norm }}$ parameter was mapped over the Hirshfeld surface (Spackman \& Jayatilaka, 2009) and fingerprint plots were produced with CrystalExplorer17.5 (Turner et al., 2017) as shown in Fig. 4. The plots indicate the structure is dominated by $\mathrm{H} \cdots \mathrm{H}$ contacts, which account for $79.1 \%$ of the total interactions. The $\mathrm{H} \cdots \mathrm{C} / \mathrm{C} \cdots \mathrm{H}$ interactions contribute $20.2 \%$ while the $\mathrm{H} \cdots \mathrm{N} / \mathrm{N} \cdots \mathrm{H}$ contacts account for only $0.7 \%$. Energy framework calculations resulted, as expected, in a major contribution of dispersive energies to the total energy, as seen in Fig. 5. The topology of the energy frameworks resemble a tilted honeycomb arrangement when viewed down the $b$-axis direction. Fig. S1 (supporting information) shows the Hirshfeld surface of a central molecule and the neighboring molecules in close contact. A comparison of $d_{\text {norm }}$, shape index and curvedness mapped onto the Hirshfeld surface is presented in Fig. S2. The absence of adjacent red
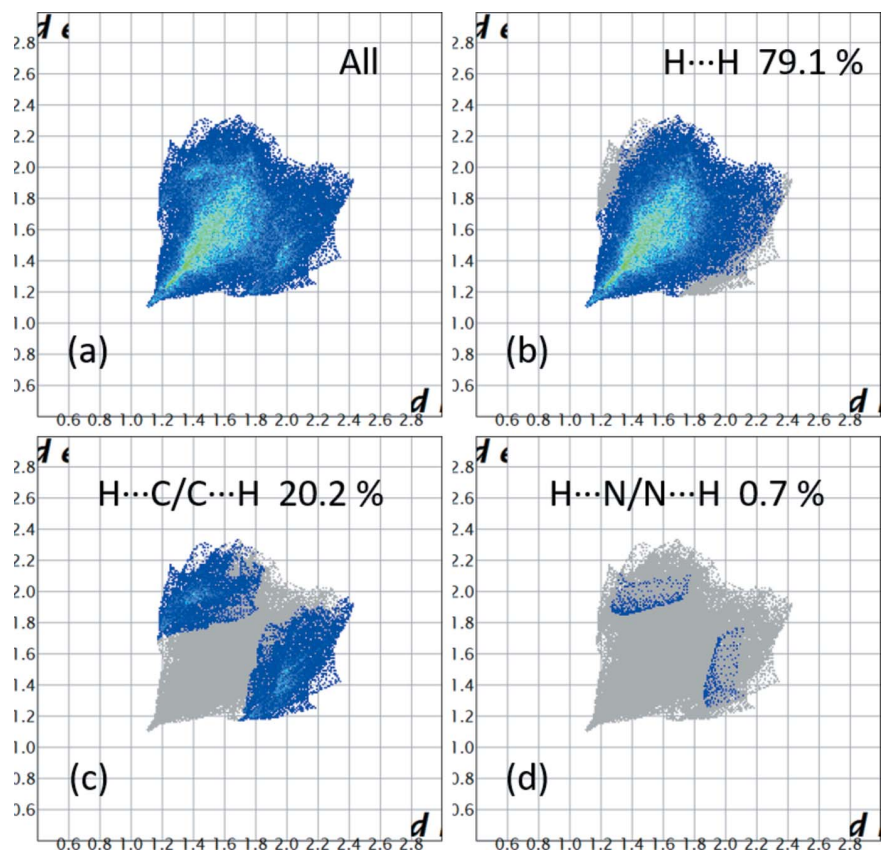

Figure 4

Fingerprint plots for the $d_{\text {norm }}$ parameter mapped onto the Hirshfeld surface for $\mathbf{3}$.
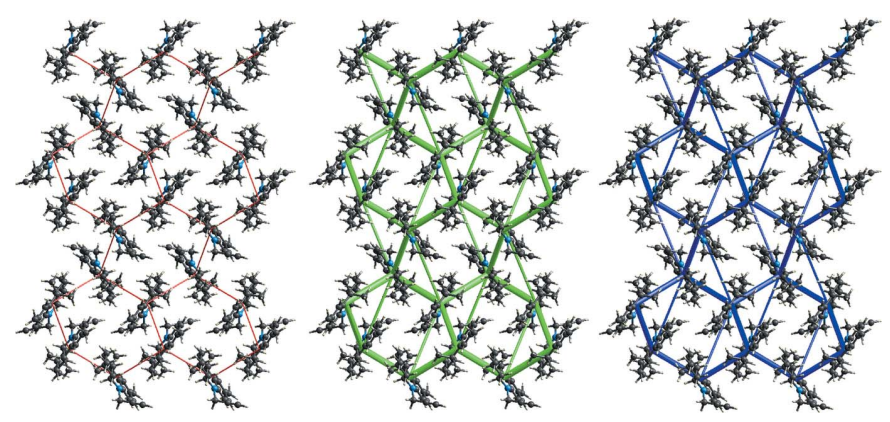

Figure 5

Energy frameworks calculated for compound $\mathbf{3}$ viewed down [010] represented within $2 \times 2 \times 2$ unit cells. The radii of the cylinders were scaled to 80 arbitrary units with a cut-off value of $10 \mathrm{~kJ} \mathrm{~mol}^{-1} . E_{\mathrm{ele}}, E_{\mathrm{dis}}$, and $E_{\text {tot }}$ are represented (left to right) in red, green, and blue, respectively.

and blue triangular motifs in the shape index and of flat areas in the curvedness plots agrees with the absence of $\pi-\pi$ interactions in the structure.

\section{Theoretical study}

The results of the calculations (Stewart, 2008, 2016, 2018) carried out with the PM6 (Stewart, 2007), PM7 (Stewart, 2013) and PM6-DH2 (Korth et al., 2010) methods for compound 3 are presented in Tables S1 to S4 of the supporting information. The best results were obtained with PM7. The excellent agreement between the experimental crystal structure and the energy-minimized structure is noted by the low RMSD $(0.023 \AA)$ as shown in Table S5. Fig. S3 shows the agreement between the experimental and the energy-minimized structure. The optimized unit-cell parameters are very close to the values obtained in the single-crystal experiments. The unsigned mean error deviation $\operatorname{UME}(a, b, c, \alpha, \beta, \gamma)$ is 0.453 . The value obtained for the density and the unit-cell volume confirmed the good accuracy of the results. The greater contribution of the dispersive forces to the heat of formation was expected after the crystallochemical and Hirshfeld analyses. Energy-related parameters calculated are summarized in Table S6.

\section{Database survey}

A search of the Cambridge Structural Database (CSD, version 5.41, November 2019, update of 2 May 2020; Groom et al., 2016) using as search criterion the $N$-propargyl-octahydroacridine moiety without any substituents, did not result in structures of this type. A further search for $N$-propargyl hydroquinolines resulted in only eight related compounds: refcodes FORCAT (Filali Baba et al., 2019), KEPRUU (Dixit et al., 2012), POWVIJ (Hayani et al., 2019), UQODUA (Suzuki et al., 2010), UROJUI and UROKAP (Shakoori et al., 2013), WIYCIR (Suzuki et al., 2008) and XILYUP (Filali Baba et al., 2017). Of these compounds, KEPRUU is perhaps the most closely related to the compound reported here. However, 
Table 1

Analytical data for 3: ATR-FTIR, IE-MS, ${ }^{1} \mathrm{H}-\mathrm{NMR},{ }^{13} \mathrm{C}-\mathrm{NMR}$.

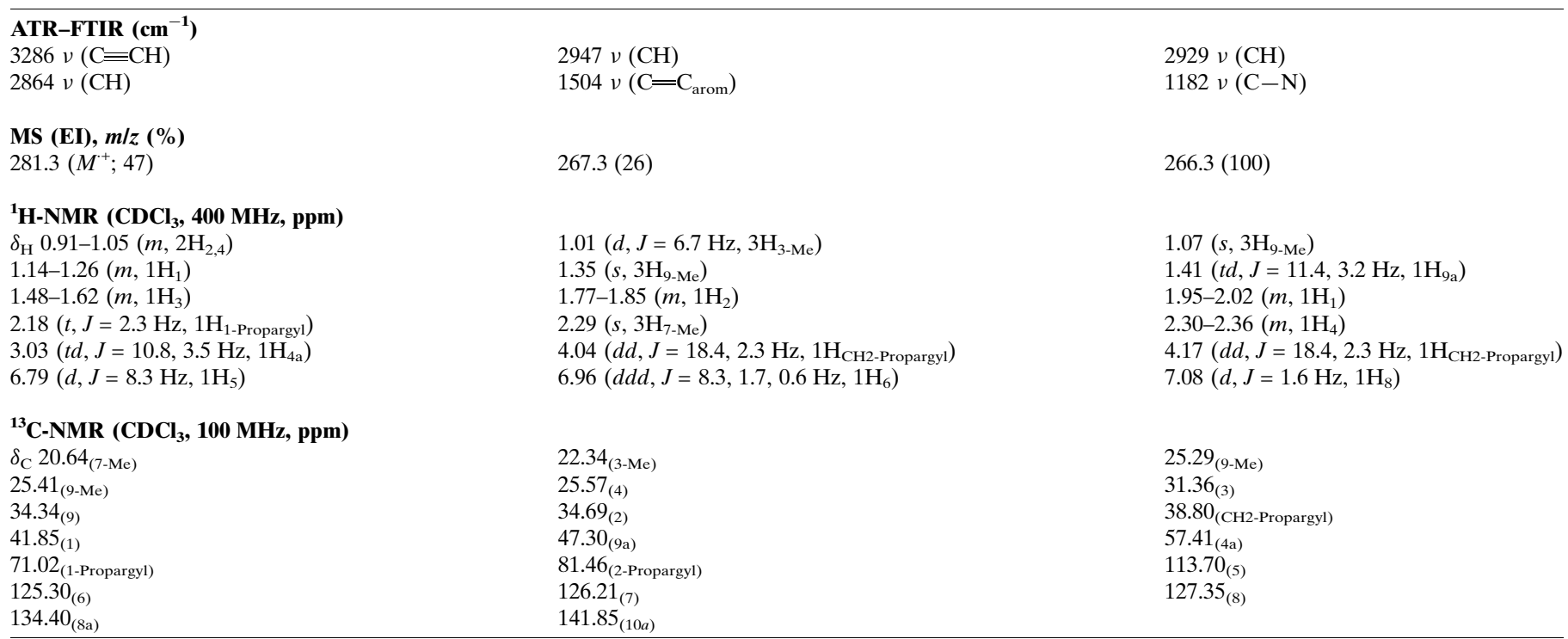

Signals were designated as: $s$, singlet; $d$, doublet; $d d$, doublet of doublets; $d d d$, doublet of doublets of doublets; $t$, triplet; $t d$, triplet of doublets; $q$, quartet; $m$, multiplet; $b r$., broad.

it contains substituents ( $\mathrm{F}, \mathrm{Cl}$, oxo, and ethyl carboxylate), which would render a richer display of intermolecular interactions.

\section{Synthesis and crystallization}

All reagents were purchased from Merck and used without additional purification. $N$-Propargyl-4-methylaniline was prepared (see scheme below) according to a previously reported procedure (Sakai et al., 2017). TLC aluminum sheets PF254 from Merck were employed to monitor the reaction progress. Column chromatography was performed using silica gel (60-120 mesh). The melting point (uncorrected) was determined using a Fisher-Johns melting point apparatus. A solution of $\mathrm{N}$-propargyl-4-methylaniline $(\mathbf{1}, 0.449 \mathrm{~g}$,

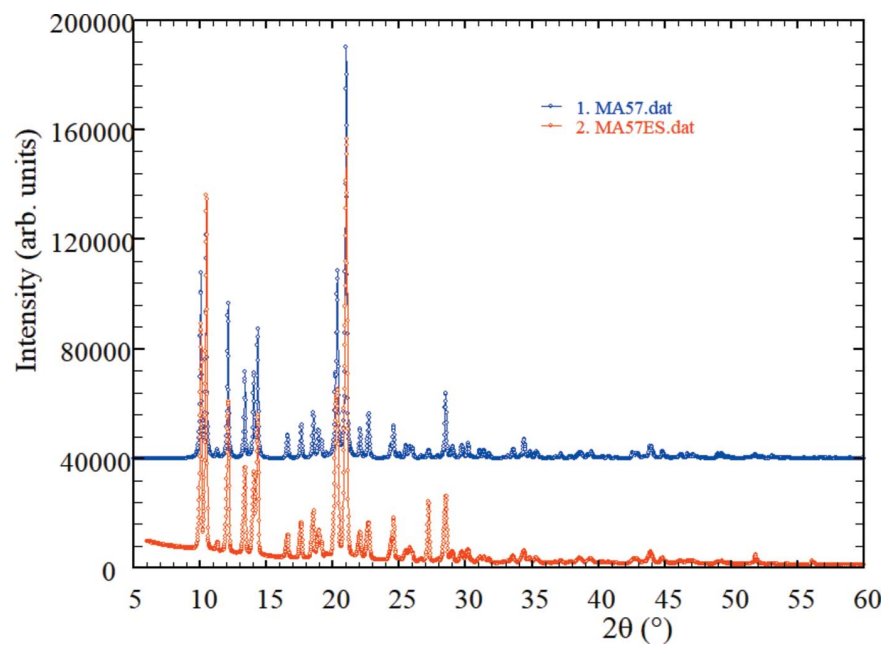

Figure 6

X-ray powder diffraction patterns of compound 3. Experimental (bottom, red) and simulated from single-crystal data (top, blue).
$3.09 \mathrm{mmol})$ and $( \pm)$-citronellal $(2,0.477 \mathrm{~g}, 3.09 \mathrm{mmol})$ in $5 \mathrm{ml}$ of acetonitrile was poured into a $50 \mathrm{ml}$ round-bottom flask and stirred at room temperature for $10 \mathrm{~min}$; the catalyst $\mathrm{BiCl}_{3}$ $(0.097 \mathrm{~g}, 10 \mathrm{~mol} \%)$ was then added to the mixture. After $6 \mathrm{~h}$ of reaction as indicated by TLC, $15 \mathrm{ml}$ of a saturated $\mathrm{NaHCO}_{3}$ aqueous solution was added and the crude product was extracted with ethyl acetate $(20 \mathrm{ml} \times 3)$ and dried over $\mathrm{Na}_{2} \mathrm{SO}_{4}$. The cis/trans octahydroacridine mixture (1:9 determined by GC) was purified using petroleum ether (b.p. 313$333 \mathrm{~K})$ as eluent. Further recrystallization from petroleum ether solution gave only the trans product (3) (see reaction scheme). Yellow solid, m.p. 347-348 K. (0.625 g) 72\% yield. Analysis calculated for $\mathrm{C}_{20} \mathrm{H}_{27} \mathrm{~N}$ : C, 85.35; H, 9.67; N, 4.98\%. Found: C, 85.87; H, 9.52; N, 5.05\%.

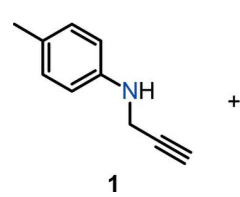

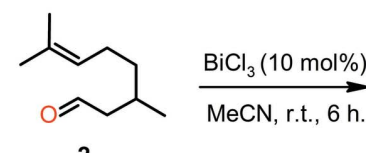

2

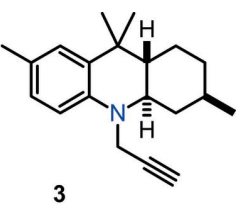

\section{X-ray powder diffraction}

The powder pattern recorded was indexed on a primitive orthorhombic unit cell with $a=15.650$ (3), $b=10.626$ (2), $c=$ 10.054 (1) $\AA, V=1672.1$ (2) $\AA^{3}$, using DICVOL14 (Louër \& Boultif, 2014), in excellent agreement with the unit-cell parameters obtained from the single-crystal data collection. All 61 diffraction maxima registered were indexed with good figures-of-merit: $M_{20}=23.8$ (de Wolff et al., 1968) and $F_{20}=$ $63.4(0.0096,33)$ (Smith \& Snyder, 1979). Since the powder diffraction pattern of this material has not been previously reported, the data have been sent to the International Center for Diffraction Data (ICDD) for its inclusion in the Powder 

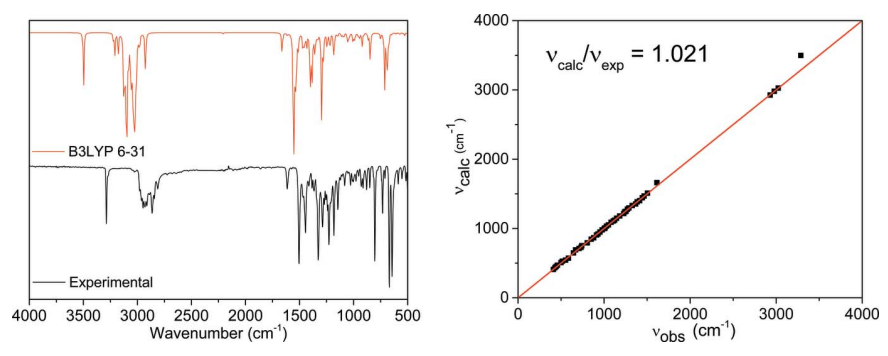

Figure 7

Experimental and calculated (B3LYP 6-31) IR spectra of compound 3 and Correlation between calculated $v_{\text {calc }}$ and observed $v_{\text {obs }}$ frequencies.

Diffraction File (Gates-Rector \& Blanton, 2019). As can be seen in Fig. 6, the pattern recorded looks almost identical to the pattern calculated using the structural data obtained from the single-crystal structure-determination process. The absence of impurity lines in the powder diffraction pattern recorded confirms that the synthetic route employed produced selectively the desired compound.

\section{Spectroscopic characterization}

The results are summarized in Table 1. The ATR-FTIR spectrum (Fig. 7) shows the absence of the $\mathrm{N}-\mathrm{H}$ and $\mathrm{C}=\mathrm{O}$ stretch bands around 3350 and $1740 \mathrm{~cm}^{-1}$, indicating complete reaction of the aniline and citronellal precursors, respectively. The assignment and confirmation of fundamental vibrational modes was performed by direct correlation after geometry optimization and vibrational frequency calculations (Neugebauer \& Hess, 2003) carried out with Gaussian 09 (Frisch et al., 2009) using the B3LYP/6-31 basis set (Hehre et al., 1972; Petersson \& Al-Laham, 1991). High accuracy is observed for vibrational frequencies in the $1500-500 \mathrm{~cm}^{-1}$ range (Fig. 7). However, for vibrations above $1500 \mathrm{~cm}^{-1}$, an increase in the error between the observed and calculated frequencies is more noticeable, as previously described for other DFT vibrational studies (Matsuura \& Yoshida, 2006). A sharp and strong signal at $3286 \mathrm{~cm}^{-1}$, attributed to the $\mathrm{C} \equiv \mathrm{CH}$ stretch, serves as evidence of the propargyl $N$-substituent group

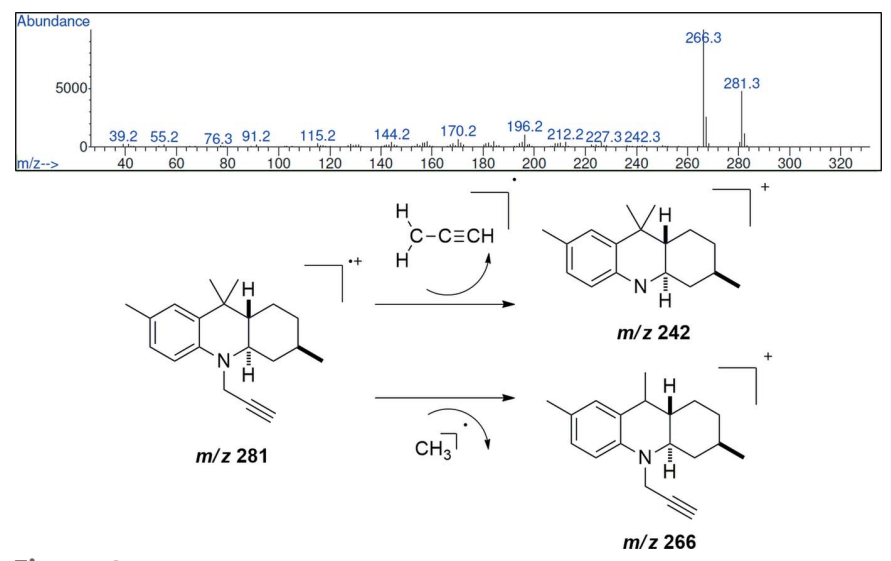

Figure 8

EI $(70 \mathrm{eV})$ mass spectrum of $\mathbf{3}$ and main fragmentation pattern observed in the MS spectrum.

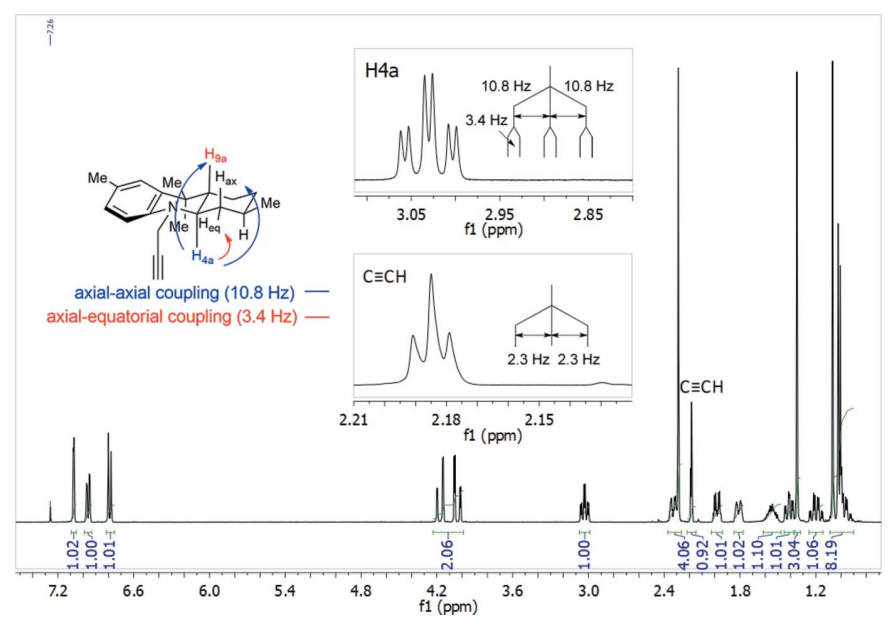

Figure 9

${ }^{1} \mathrm{H}$-NMR spectrum for 3 . The inserts emphasize the alkyne proton region and the assignment of a trans-fusion pattern of rings $A$ and $B$.

presence. An additional absorption band at $3024 \mathrm{~cm}^{-1}$ is observed and corresponds to the aromatic $\mathrm{C}-\mathrm{H}$ stretch in the OHA molecule. Absorptions at 1614 and $1504 \mathrm{~cm}^{-1}$ are attributed to the $\mathrm{C}=\mathrm{C}$ aromatic stretch and the band at $1182 \mathrm{~cm}^{-1}$ is assigned to the $\mathrm{C}-\mathrm{N}$ stretch vibration.

The mass spectrum (EI, $70 \mathrm{eV}$ ) for the title compound is depicted in Fig. 8. The molecular ion at $281.3 \mathrm{~m} / \mathrm{z}$ is observed with a relative intensity of $47 \%$ and it is in accordance with the molecular formula $\mathrm{C}_{20} \mathrm{H}_{27} \mathrm{~N}$. Peaks at 266 and $242 \mathrm{~m} / \mathrm{z}$ are attributed to fragmentations involving the loss of a methyl group inducing the formation of a very stable benzylic tertiary cation and the loss of the propargyl fragment, respectively.

The ${ }^{1} \mathrm{H}$-NMR spectrum (Fig. 9) shows the aromatic signals at downfield as doublets and doublet of doublets with their corresponding ${ }^{3} J$ and ${ }^{4} J$ values of 8.3 and $1.7 \mathrm{~Hz}$, respectively. The methylenic protons of the propargyl moiety appear as two doublets of doublets at 4.04 and $4.17 \mathrm{ppm}$. Two singlets at 1.03 and $1.35 \mathrm{ppm}$ correspond to the methyl groups bonded to $C-9$. The difference in their chemical shift values is the result of a distinct chemical environment due to a specific and non-

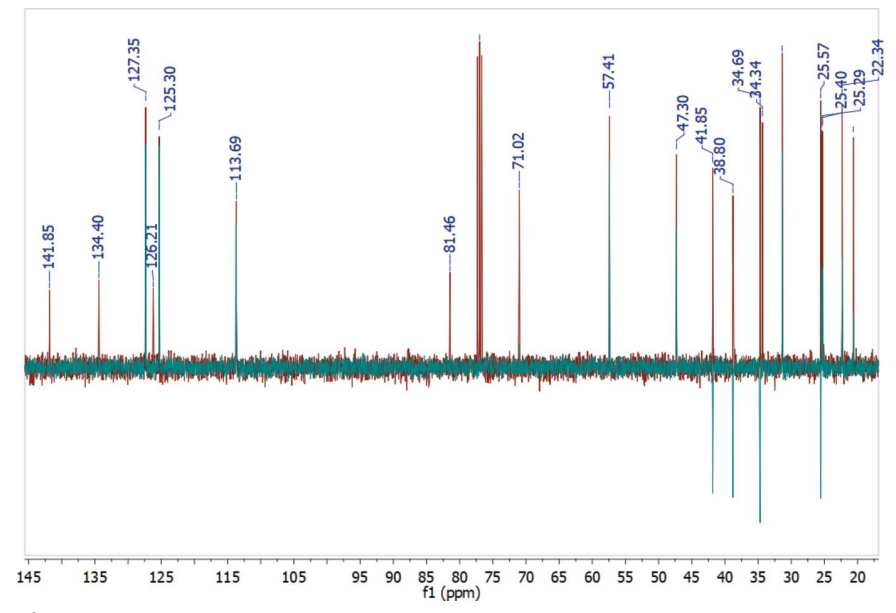

Figure 10

${ }^{13}$ C-NMR and DEPT-135 spectra. 
Table 2

Experimental details.

\begin{tabular}{|c|c|}
\hline \multicolumn{2}{|l|}{ Crystal data } \\
\hline Chemical formula & $\mathrm{C}_{20} \mathrm{H}_{27} \mathrm{~N}$ \\
\hline$M_{\mathrm{r}}$ & 281.42 \\
\hline Crystal system, space group & Orthorhombic, $P 2_{1} 2_{1} 2_{1}$ \\
\hline Temperature (K) & 293 \\
\hline$a, b, c(\AA)$ & $\begin{array}{l}10.05103(9), 10.62943(11), \\
15.64759(16)\end{array}$ \\
\hline$V\left(\AA^{3}\right)$ & $1671.74(3)$ \\
\hline$Z$ & 4 \\
\hline Radiation type & $\mathrm{Cu} K \alpha$ \\
\hline$\mu\left(\mathrm{mm}^{-1}\right)$ & 0.48 \\
\hline Crystal size $(\mathrm{mm})$ & $0.48 \times 0.33 \times 0.29$ \\
\hline \multicolumn{2}{|l|}{ Data collection } \\
\hline Diffractometer & Rigaku Pilatus 200K \\
\hline Absorption correction & $\begin{array}{l}\text { Multi-scan (CrysAlis PRO; Rigaku } \\
\text { OD, 2019) }\end{array}$ \\
\hline$T_{\min }, T_{\max }$ & $0.573,1.000$ \\
\hline $\begin{array}{l}\text { No. of measured, independent and } \\
\text { observed }[I>2 \sigma(I)] \text { reflections }\end{array}$ & $6660,3181,3160$ \\
\hline$R_{\text {int }}$ & 0.013 \\
\hline$(\sin \theta / \lambda)_{\max }\left(\AA^{-1}\right)$ & 0.624 \\
\hline \multicolumn{2}{|l|}{ Refinement } \\
\hline$R\left[F^{2}>2 \sigma\left(F^{2}\right)\right], w R\left(F^{2}\right), S$ & $0.039,0.107,1.11$ \\
\hline No. of reflections & 3181 \\
\hline No. of parameters & 195 \\
\hline $\mathrm{H}$-atom treatment & $\mathrm{H}$-atom parameters constrained \\
\hline$\Delta \rho_{\max }, \Delta \rho_{\min }\left(\mathrm{e} \AA^{-3}\right)$ & $0.15,-0.19$ \\
\hline Absolute structure & $\begin{array}{l}\text { Flack } x \text { determined using } 1267 \\
\quad \text { quotients }\left[\left(I^{+}\right)-\left(I^{-}\right)\right] /\left[\left(I^{+}\right)+\left(I^{-}\right)\right] \\
\quad \text { (Parsons } \text { et al., } 2013)\end{array}$ \\
\hline Absolute structure parameter & $0.3(2)$ \\
\hline
\end{tabular}

Computer programs: CrystalClear-SM Expert (Rigaku/MSC, 2015), CrysAlis PRO (Rigaku OD, 2019), SHELXT2014/5 (Sheldrick, 2015a), SHELXL2018/3 (Sheldrick, 2015b), DIAMOND (Brandenburg, 1999), OLEX2 (Dolomanov et al., 2009), enCIFer (Allen et al., 2004) and publCIF (Westrip, 2010).

interchangeable molecular conformation adopted by the OHA. The alkyne proton at $2.18 \mathrm{ppm}$ appears as a triplet with ${ }^{4} J=2.3 \mathrm{~Hz}$. The signal for the proton $H-4 a$ at $3.04 \mathrm{ppm}(t d, J=$ $10.8 ; 3.4 \mathrm{~Hz}$ ) plays a key role in the spectroscopic determination of the OHA stereochemistry. It suggests two pseudoaxial $(10.8 \mathrm{~Hz})$ and one pseudoequatorial $(3.4 \mathrm{~Hz})$ spin couplings which are characteristic of a trans geometry in fused rings, as observed in Fig. 9. All other aliphatic signals are located at high field, mainly as multiplets. The ${ }^{13} \mathrm{C}-\mathrm{NMR}$ spectrum, shown in Fig. 10, displays the characteristic signals for the propargyl group at 71.02 and $81.46 \mathrm{ppm}$. The signals for the methyl groups at $C-9$ also have different chemical shift values, observed at 25.0 and $25.2 \mathrm{ppm}$. The determination of quaternary carbon atoms and differentiation between methyl, methylenic and methynic groups was achieved using the DEPT-135 spectrum (Fig. 10).

\section{Refinement}

Crystal data, data collection and structure refinement details are summarized in Table 2. Hydrogen atoms were identified in the difference-Fourier map but were included in geometrically calculated positions $(\mathrm{C}-\mathrm{H}=0.93-0.98 \AA)$ and refined as riding with $U_{\text {iso }}(\mathrm{H})=1.2-1.5 U_{\mathrm{eq}}(\mathrm{C})$.

\section{Acknowledgements}

The authors thank Laboratorio de Rayos X of Universidad Industrial de Santander (UIS), Colombia, and the support of Vicerrectoría de Investigación y Extensión of UIS. Access to the Cambridge Structural Database (CSD) for Universidad de Los Andes (Venezuela) was possible through the Frank $H$. Allen International Research \& Education Programme (FAIRE) from the Cambridge Crystallographic Data Centre (CCDC).

\section{Funding information}

Funding for this research was provided by: Universidad Industrial de Santander, Vicerrectoría de Investigación y Extensión.

\section{References}

Acelas, M., Bohórquez, A. \& Kouznetsov, V. V. (2017). Synthesis, 49, 2153-2162.

Acelas, M., Camargo, H. A., Henao, J. A., Kouznetsov, V. V., Romero Bohórquez, A. R., Dugarte-Dugarte, A., Delgado, J. M. \& Díaz de Delgado, G. (2020). J. Mol. Struct. 1215, 128222-, 1-12822211.

Acelas, M., Kouznetsov, V. V. \& Romero Bohórquez, A. R. (2019). Mol. Divers. 23, 183-193.

Allen, F. H., Johnson, O., Shields, G. P., Smith, B. R. \& Towler, M. (2004). J. Appl. Cryst. 37, 335-338.

Brandenburg, K. (1999). DIAMOND. Crystal Impact GbR, Bonn, Germany.

Del Giudice, M. R., Borioni, A., Mustazza, C. \& Gatta, F. (1997). J. Heterocycl. Chem. 34, 1661-1667.

Dixit, S. K., Mishra, N., Sharma, M., Singh, S., Agarwal, A., Awasthi, S. K. \& Bhasin, V. K. (2012). Eur. J. Med. Chem. 51, 52-59.

Dolomanov, O. V., Bourhis, L. J., Gildea, R. J., Howard, J. A. K. \& Puschmann, H. (2009). J. Appl. Cryst. 42, 339-341.

Ermolaeva, V. G., Yashunskii, V. G., Polezhaeva, A. I. \& Mashkovskii, M. D. (1968). Pharm. Chem. J. 2, 310-312.

Filali Baba, Y., Hayani, S., Kaur, M., Jasinski, J. P., Sebbar, N. K. \& Rodi, Y. (2019). Private Communication (refcode FORCAT). CCDC, Cambridge, England

Filali Baba, Y., Kandri Rodi, Y., Jasinski, J. P., Kaur, M., Ouzidan, Y. \& Essassi, E. M. (2017). IUCrData, 2, x171072.

Frisch, M. J., Trucks, G. W., Schlegel, H. B., Scuseria, G. E., Robb, M. A., Cheeseman, J. R., Scalmani, G., Barone, V., Mennucci, B., Petersson, G. A., Nakatsuji, H., Caricato, M., Li, X., Hratchian, H. P., Izmaylov, A. F., Bloino, J., Zheng, G., Sonnenberg, J. L., Hada, M., Ehara, M., Toyota, K., Fukuda, R., Hasegawa, J., Ishida, M., Nakajima, T., Honda, Y., Kitao, O., Nakai, H., Vreven, T., Montgomery, J. A. Jr, Peralta, J. E., Ogliaro, F., Bearpark, M., Heyd, J. J., Brothers, E., Kudin, K. N., Staroverov, V. N., Kobayashi, R., Normand, J., Raghavachari, K., Rendell, A., Burant, J. C., Iyengar, S. S., Tomasi, J., Cossi, M., Rega, N., Millam, J. M., Klene, M., Knox, J. E., Cross, J. B., Bakken, V., Adamo, C., Jaramillo, J., Gomperts, R., Stratmann, R. E., Yazyev, O., Austin, A. J., Cammi, R., Pomelli, C., Ochterski, J. W., Martin, R. L., Morokuma, K., Zakrzewski, V. G., Voth, G. A., Salvador, P., Dannenberg, J. J., Dapprich, S., Daniels, A. D., Farkas, Ö., Foresman, J. B., Ortiz, J. V., Cioslowski, J. \& Fox, D. J. (2009). Gaussian 09, Revision A.1. Gaussian Inc., Wallingford, CT, USA.

Fröhlich, R., Grehl, M., Kramm-Glade, S. \& Laschat, S. (1994). Acta Cryst. C50, 1798-1801.

Gan, X.-M., Parveen, S., Smith, W. L., Duesler, E. N. \& Paine, R. T. (2000). Inorg. Chem. 39, 4591-4598.

Gates-Rector, S. \& Blanton, T. N. (2019). Powder Diffr. 34, 352-360. 
Groom, C. R., Bruno, I. J., Lightfoot, M. P. \& Ward, S. C. (2016). Acta Cryst. B72, 171-179.

Güiza, F. M., Duarte, Y. B., Mendez-Sanchez, S. C. \& Bohórquez, A. R. R. (2019). Med. Chem. Res. 28, 1182-1196.

Hayani, S., Filali Baba, Y., Hökelek, T., Ouazzani Chahdi, F., Mague, J. T., Sebbar, N. K. \& Kandri Rodi, Y. (2019). Acta Cryst. E75, 14111417.

Hehre, W. J., Ditchfield, R. \& Pople, J. A. (1972). J. Chem. Phys. 56, 2257-2261.

Korth, M., Pitoňák, M., Řezáč, J. \& Hobza, P. (2010). J. Chem. Theory Comput. 6, 344-352.

Kouznetsov, V. V., Palma, A., Rozo, W., Stashenko, E., Bahsas, A. \& Amaro-Luis, J. (2000). Tetrahedron Lett. 41, 6985-6988.

Li, S., Wang, J., Xia, P.-J., Zhao, Q.-L., Wang, C.-M., Xiao, J.-A., Chen, X.-Q., Xiang, H.-Y. \& Yang, H. (2018). J. Org. Chem. 83, 1228412290.

Loots, L. \& Barbour, L. J. (2012). CrystEngComm, 14, 300-304.

Louër, D. \& Boultif, A. (2014). Powder Diffr. 29, S7-S12.

Macrae, C. F., Sovago, I., Cottrell, S. J., Galek, P. T. A., McCabe, P., Pidcock, E., Platings, M., Shields, G. P., Stevens, J. S., Towler, M. \& Wood, P. A. (2020). J. Appl. Cryst. 53, 226-235.

Matsuura, H. \& Yoshida, H. (2006). Calculation of Vibrational Frequencies by Hartree-Fock-Based and Density Functional Theory. In Handbook of Vibrational Spectroscopy, edited by J. M. Chalmers and P. R. Griffiths. Wiley Online Library. https:// doi.org/10.1002/0470027320.s4203.

Müller-Schiffmann, A., Sticht, H. \& Korth, C. (2012). BioDrugs, 26, 21-31.

Neugebauer, J. \& Hess, B. A. (2003). J. Chem. Phys. 118, 7215-7225.

Parsons, S., Flack, H. D. \& Wagner, T. (2013). Acta Cryst. B69, 249 259.

Petersson, G. A. \& Al-Laham, M. A. (1991). J. Chem. Phys. 94, 60816090.

Rigaku/MSC (2015). CrystalClear. Rigaku/MSC Inc., The Woodlands, Texas, USA.
Rigaku OD (2019). CrysAlis PRO. Rigaku Oxford Diffraction, Yarnton, England.

Sakai, N., Suzuki, H., Hori, H. \& Ogiwara, Y. (2017). Tetrahedron Lett. 58, 63-66.

Sakane, S., Matsumura, Y., Yamamura, Y., Ishida, Y., Maruoka, K. \& Yamamoto, H. (1983). J. Am. Chem. Soc. 105, 672-674.

Selvaraj, M. \& Assiri, M. A. (2019). Dalton Trans. 48, 12986-12995.

Shakoori, A., Bremner, J. B., Willis, A. C., Haritakun, R. \& Keller, P. A. (2013). J. Org. Chem. 78, 7639-7647.

Sheldrick, G. M. (2015a). Acta Cryst. A71, 3-8.

Sheldrick, G. M. (2015b). Acta Cryst. C71, 3-8.

Smith, G. S. \& Snyder, R. L. (1979). J. Appl. Cryst. 12, 60-65.

Spackman, M. A. \& Jayatilaka, D. (2009). CrystEngComm, 11, 19-32.

Spek, A. L. (2020). Acta Cryst. E76, 1-11.

Stewart, J. J. P. (2007). J. Mol. Model. 13, 1173-1213.

Stewart, J. J. P. (2008). J. Mol. Model. 14, 499-535.

Stewart, J. J. P. (2013). J. Mol. Model. 19, 1-32.

Stewart, J. J. P. (2016). MOPAC2016. Version 18.258W. Stewart Computational Chemistry, Colorado Springs, CO, USA.

Stewart, J. J. P. (2018). MAKPOL. Stewart Computational Chemistry, Colorado Springs, CO, USA.

Suzuki, T., Ohta, K., Nehira, T., Higuchi, H., Ohta, E., Kawai, H. \& Fujiwara, K. (2008). Tetrahedron Lett. 49, 772-776.

Suzuki, T., Yoshimoto, Y., Wada, K., Takeda, T., Kawai, H. \& Fujiwara, K. (2010). Heterocycles, 80, 149-155.

Turner, M. J., McKinnon, J. J., Wolff, S. K., Grimwood, D. J., Spackman, P. R., Jayatilaka, D. \& Spackman, M. A. (2017). CrystalExplorer17.5. The University of Western Australia.

Ulus, R., Kaya, M., Demir, D., Tunca, E. \& Bülbül, M. (2016). J. Enzyme Inhib. Med. Chem. 31, 63-69.

Westrip, S. P. (2010). J. Appl. Cryst. 43, 920-925.

Wolff, P. M. de (1968). J. Appl. Cryst. 1, 108-113.

Wu, H. \& Wang, Y. M. (2014). Chem. Eur. J. 20, 5899-5904.

Zaliznaya, E. V., Farat, O. K., Varenichenko, S. A., Mazepa, A. V. \& Markov, V. I. (2016). Tetrahedron Lett. 57, 3485-3487. 


\section{supporting information}

Acta Cryst. (2021). E77, 226-232 [https://doi.org/10.1107/S2056989021001183]

Synthesis, crystal structure, Hirshfeld surface analysis and energy framework calculations of trans-3,7,9,9-tetramethyl-10-(prop-2-yn-1-yl)-1,2,3,4,4a,9,9a,10octahydroacridine

\section{Mauricio Acelas, Analio Dugarte-Dugarte, Arnold R. Romero Bohórquez, José Antonio}

Henao, José Miguel Delgado and Graciela Díaz de Delgado

Computing details

Data collection: CrystalClear-SM Expert (Rigaku/MSC, 2015); cell refinement: CrysAlis PRO (Rigaku OD, 2019); data reduction: CrysAlis PRO (Rigaku OD, 2019); program(s) used to solve structure: SHELXT2014/5 (Sheldrick, 2015a); program(s) used to refine structure: SHELXL2018/3 (Sheldrick, 2015b); molecular graphics: DIAMOND (Brandenburg, 1999); software used to prepare material for publication: OLEX2 (Dolomanov et al., 2009), enCIFer (Allen et al., 2004) and publCIF (Westrip, 2010).

trans-3,7,9,9-Tetramethyl-10-(prop-2-yn-1-yl)-1,2,3,4,4a,9,9a,10-octahydroacridine

Crystal data

$\mathrm{C}_{20} \mathrm{H}_{27} \mathrm{~N}$

$M_{r}=281.42$

Orthorhombic, $P 2_{1} 2_{1} 2_{1}$

$a=10.05103$ (9) $\AA$

$b=10.62943(11) \AA$

$c=15.64759(16) \AA$

$V=1671.74(3) \AA^{3}$

$Z=4$

$F(000)=616$

Data collection

Rigaku Pilatus 200K diffractometer

Radiation source: fine-focus sealed X-ray tube, Enhance $(\mathrm{Cu}) \mathrm{X}$-ray Source

Graphite monochromator Detector resolution: 5.8140 pixels $\mathrm{mm}^{-1}$

profile data from $\omega$-scans

Absorption correction: multi-scan

(CrysAlisPRO; Rigaku OD, 2019)

Refinement

Refinement on $F^{2}$

Least-squares matrix: full

$R\left[F^{2}>2 \sigma\left(F^{2}\right)\right]=0.039$

$w R\left(F^{2}\right)=0.107$
$D_{\mathrm{x}}=1.118 \mathrm{Mg} \mathrm{m}^{-3}$

Melting point: $367 \mathrm{~K}$

$\mathrm{Cu} K \alpha$ radiation, $\lambda=1.54184 \AA$

Cell parameters from 6301 reflections

$\theta=2.8-74.2^{\circ}$

$\mu=0.48 \mathrm{~mm}^{-1}$

$T=293 \mathrm{~K}$

Block, colorless

$0.48 \times 0.33 \times 0.29 \mathrm{~mm}$

$T_{\min }=0.573, T_{\max }=1.000$

6660 measured reflections

3181 independent reflections

3160 reflections with $I>2 \sigma(I)$

$R_{\text {int }}=0.013$

$\theta_{\max }=74.2^{\circ}, \theta_{\min }=5.7^{\circ}$

$h=-9 \rightarrow 11$

$k=-11 \rightarrow 13$

$l=-19 \rightarrow 19$

$S=1.11$

3181 reflections

195 parameters

0 restraints 
Primary atom site location: dual

Secondary atom site location: difference Fourier map

Hydrogen site location: inferred from neighbouring sites

$\mathrm{H}$-atom parameters constrained

$w=1 /\left[\sigma^{2}\left(F_{\mathrm{o}}^{2}\right)+(0.0679 P)^{2}+0.0783 P\right]$

where $P=\left(F_{\mathrm{o}}{ }^{2}+2 F_{\mathrm{c}}{ }^{2}\right) / 3$

$(\Delta / \sigma)_{\max }<0.001$

$\Delta \rho_{\max }=0.15$ e $\AA^{-3}$

\section{Special details}

Experimental. Characterization by X-ray powder diffraction

A small portion of the synthesized material, previously grounded in an agate mortar, was dusted on top of a flat plate low-background Si single crystal specimen holder. The powder diffraction pattern was registered at room temperature on a Bruker D8 ADVANCE diffractometer working in the Bragg-Brentano geometry using $\mathrm{Cu}$ Ka radiation, operating at 40 $\mathrm{kV}$ and $30 \mathrm{~mA}$, and equipped with a LynxEye position-sensitive detector. The pattern was recorded from 6.00 to $70.00^{\circ}$

$(2 \theta)$ in steps of $0.01526^{\circ}$, at $1 \mathrm{sec} / \mathrm{step}$. The standard instrument settings (Ni filter of $0.02 \mathrm{~mm}$, Soller slits of $2.5^{\circ}$, Divergence slit of $0.2 \mathrm{~mm}$, scatter screen height of $3 \mathrm{~mm}$ ) were employed.

Characterization by ATR-FTIR, mass spectrometry, elemental analysis, and ${ }^{1} \mathrm{H}$ - and ${ }^{13} \mathrm{C}-\mathrm{NMR}$

The IR spectrum was recorded in the region from 4000 to $500 \mathrm{~cm}^{-1}$ on a Bruker Tensor 27 FTIR spectrophotometer coupled to a Bruker platinum ATR cell. Vibrational frequencies were calculated by the B3LYP method with a 6-31G basis set, as a strategy to correlate the experimental bands with their corresponding vibrational modes (Matsuura and Yoshida, 2006). The mass spectrum was recorded on a Hewlett Packard 5890a Series II Gas Chromatograph interfaced to an HP MS ChemStation Data System at $70 \mathrm{eV}$ using a $60 \mathrm{~m}$ capillary column coated with HP-5 [5\%

phenylpoly(dimethylsiloxane)]. Elemental analysis was performed on a Thermo Scientific CHNS-O analyzer (Model Flash 2000) and the experimental values were within \pm 0.4 of the theoretical values. NMR spectra $\left({ }^{1} \mathrm{H}\right.$ and $\left.{ }^{13} \mathrm{C}\right)$ were measured on a Bruker Ultrashield-400 spectrometer (400 MHz ${ }^{1} \mathrm{H}$ NMR and $100 \mathrm{MHz}{ }^{13} \mathrm{C} \mathrm{NMR}$ ), using $\mathrm{CDCl}_{3}$ as solvent and reference. $J$ values are reported in $\mathrm{Hz}$; chemical shifts are reported in ppm $(\delta)$ relative to the solvent peak (residual $\mathrm{CHCl}_{3}$ in $\mathrm{CDCl}_{3}$ at $7.26 \mathrm{ppm}$ for protons). Signals were designated as: s, singlet; d, doublet; dd, doublet of doublets; ddd, doublet of doublets of doublets; t, triplet; td, triplet of doublets; q, quartet; m, multiplet; br., broad. Geometry and energy optimization

Semi-empirical quantum chemistry calculations were performed to evaluate the crystalline structure determined using single crystal X-ray diffraction techniques. The calculations were carried out using the treatment of periodic boundary conditions (Stewart, 2008) implemented in the MOPAC2016 package (Stewart, 2016). A laptop equipped with 1.60GHz Intel(R) Core(TM) i5-8250U CPU, 8Gb memory, and a Windows 10 operating system was used. To minimize border effects and obtain a full structure representation of the compound under study, the crystallographic unit cell was replicated $1, \mathrm{~m}$, and $\mathrm{n}$ times along the corresponding Cartesian axes. In each case, the keyword MERS $=(1, \mathrm{~m}, \mathrm{n})$ was used, where $1, \mathrm{~m}$, and $\mathrm{n}$ could be either 1 or 2 . Using the experimental crystal structure parameters, an input cluster of molecules for the compound was created using Mercury (Macrae et al., 2020) and MAKPOL (Stewart, 2018). The studied clusters consisted of 768 and 384 atoms. The geometry was energy minimized using the L-BFGS-B function minimizer with the PM6 (Stewart, 2007), PM7 (Stewart, 2013) and PM6-DH2 (Korth et al., 2010) methods, allowing the unit cell parameters and the atomic coordinates of all 768 and 384 atoms to vary in every case. The calculation was set to terminate when the gradient norm reached a value $<10 \mathrm{Kcal}$ mol- $1 \AA^{-1}$. The optimized atomic positions were visualized and compared to the experimental atomic coordinates using the Crystal Packing Similarity capability of Mercury.

Geometry. All esds (except the esd in the dihedral angle between two 1.s. planes) are estimated using the full covariance matrix. The cell esds are taken into account individually in the estimation of esds in distances, angles and torsion angles; correlations between esds in cell parameters are only used when they are defined by crystal symmetry. An approximate (isotropic) treatment of cell esds is used for estimating esds involving 1.s. planes.

Fractional atomic coordinates and isotropic or equivalent isotropic displacement parameters $\left(A^{2}\right)$

\begin{tabular}{lllll}
\hline & $x$ & $y$ & $z$ & $U_{\text {iso }} * / U_{\text {eq }}$ \\
\hline N1 & $0.38131(16)$ & $0.67573(14)$ & $0.32881(9)$ & $0.0587(4)$
\end{tabular}




\begin{tabular}{|c|c|c|c|c|}
\hline $\mathrm{C} 1$ & $0.5388(2)$ & $0.6967(2)$ & 0.54905 (12) & $0.0651(5)$ \\
\hline $\mathrm{H} 1 \mathrm{~A}$ & 0.522689 & 0.649842 & 0.601246 & $0.078^{*}$ \\
\hline H1B & 0.631139 & 0.684239 & 0.533165 & $0.078^{*}$ \\
\hline $\mathrm{C} 2$ & $0.5154(2)$ & $0.8351(2)$ & $0.56596(13)$ & $0.0698(5)$ \\
\hline $\mathrm{H} 2 \mathrm{~A}$ & 0.425363 & 0.847263 & 0.586694 & $0.084^{*}$ \\
\hline $\mathrm{H} 2 \mathrm{~B}$ & 0.576286 & 0.863906 & 0.609906 & $0.084 *$ \\
\hline $\mathrm{C} 3$ & $0.53583(17)$ & $0.91189(18)$ & $0.48576(13)$ & $0.0620(4)$ \\
\hline H3 & 0.628642 & 0.900743 & 0.468121 & $0.074 *$ \\
\hline $\mathrm{C} 4$ & $0.44845(17)$ & $0.86058(16)$ & $0.41413(12)$ & $0.0566(4)$ \\
\hline $\mathrm{H} 4 \mathrm{~A}$ & 0.466096 & 0.907853 & 0.362330 & $0.068^{*}$ \\
\hline H4B & 0.355835 & 0.873562 & 0.429161 & $0.068^{*}$ \\
\hline $\mathrm{C} 5$ & $0.47082(15)$ & $0.72069(16)$ & $0.39624(10)$ & $0.0508(4)$ \\
\hline H5 & 0.562872 & 0.708887 & 0.377202 & $0.061^{*}$ \\
\hline C6 & $0.44943(15)$ & $0.64426(16)$ & $0.47810(9)$ & $0.0484(4)$ \\
\hline H6 & 0.357383 & 0.659273 & 0.496077 & $0.058^{*}$ \\
\hline $\mathrm{C} 7$ & $0.34579(16)$ & $0.54953(16)$ & $0.32338(9)$ & $0.0517(4)$ \\
\hline $\mathrm{C} 8$ & $0.38003(15)$ & $0.46188(15)$ & $0.38711(9)$ & $0.0492(4)$ \\
\hline C9 & $0.46345(16)$ & $0.50046(17)$ & $0.46439(9)$ & $0.0513(4)$ \\
\hline $\mathrm{C} 10$ & $0.27175(19)$ & $0.50620(18)$ & $0.25324(11)$ & $0.0621(4)$ \\
\hline H10 & 0.246012 & 0.563166 & 0.211266 & $0.075^{*}$ \\
\hline $\mathrm{C} 11$ & $0.23606(19)$ & $0.38138(19)$ & $0.24481(12)$ & $0.0648(5)$ \\
\hline H11 & 0.188546 & 0.355866 & 0.196845 & $0.078^{*}$ \\
\hline $\mathrm{C} 12$ & $0.26960(18)$ & $0.29373(18)$ & $0.30627(12)$ & $0.0620(4)$ \\
\hline $\mathrm{C} 13$ & $0.34035(17)$ & $0.33742(17)$ & $0.37640(11)$ & $0.0579(4)$ \\
\hline H13 & 0.362622 & 0.279976 & 0.418889 & $0.069^{*}$ \\
\hline C14 & $0.5139(2)$ & $1.0515(2)$ & $0.49995(16)$ & $0.0780(6)$ \\
\hline $\mathrm{H} 14 \mathrm{~A}$ & 0.423655 & 1.065695 & 0.517634 & $0.117^{*}$ \\
\hline H14B & 0.530617 & 1.096137 & 0.447712 & $0.117^{*}$ \\
\hline $\mathrm{H} 14 \mathrm{C}$ & 0.573460 & 1.081061 & 0.543498 & $0.117^{*}$ \\
\hline $\mathrm{C} 15$ & $0.2335(3)$ & $0.1564(2)$ & $0.29657(17)$ & $0.0872(7)$ \\
\hline H15A & 0.222116 & 0.119406 & 0.352062 & $0.131^{*}$ \\
\hline H15B & 0.303458 & 0.113374 & 0.266677 & $0.131 *$ \\
\hline $\mathrm{H} 15 \mathrm{C}$ & 0.152176 & 0.149164 & 0.264824 & $0.131 *$ \\
\hline $\mathrm{C} 16$ & $0.60856(18)$ & $0.4612(2)$ & $0.44781(13)$ & $0.0689(5)$ \\
\hline H16A & 0.662066 & 0.482466 & 0.496540 & $0.103 *$ \\
\hline H16B & 0.641587 & 0.504656 & 0.398371 & $0.103 *$ \\
\hline $\mathrm{H} 16 \mathrm{C}$ & 0.612541 & 0.372124 & 0.438170 & $0.103 *$ \\
\hline $\mathrm{C} 17$ & $0.4133(2)$ & $0.43261(19)$ & $0.54534(11)$ & $0.0659(5)$ \\
\hline H17A & 0.463342 & 0.460816 & 0.593947 & $0.099 *$ \\
\hline H17B & 0.424506 & 0.343467 & 0.538626 & $0.099 *$ \\
\hline $\mathrm{H} 17 \mathrm{C}$ & 0.320781 & 0.451316 & 0.553822 & $0.099 *$ \\
\hline $\mathrm{C} 18$ & $0.37514(19)$ & $0.74991(18)$ & $0.24998(11)$ & $0.0614(4)$ \\
\hline H18A & 0.400066 & 0.696834 & 0.202166 & $0.074 *$ \\
\hline H18B & 0.439266 & 0.817919 & 0.253479 & $0.074 *$ \\
\hline $\mathrm{C} 19$ & $0.2427(2)$ & $0.80308(18)$ & $0.23385(11)$ & $0.0646(5)$ \\
\hline $\mathrm{C} 20$ & $0.1372(3)$ & $0.8443(2)$ & $0.21983(15)$ & $0.0835(6)$ \\
\hline $\mathrm{H} 20$ & 0.053201 & 0.877163 & 0.208666 & $0.100^{*}$ \\
\hline
\end{tabular}


Atomic displacement parameters $\left(\AA^{2}\right)$

\begin{tabular}{lllllll}
\hline & $U^{11}$ & $U^{22}$ & $U^{33}$ & $U^{12}$ & $U^{13}$ & $U^{23}$ \\
\hline $\mathrm{N} 1$ & $0.0707(9)$ & $0.0631(8)$ & $0.0422(7)$ & $-0.0078(7)$ & $-0.0101(6)$ & $0.0074(6)$ \\
$\mathrm{C} 1$ & $0.0652(10)$ & $0.0769(11)$ & $0.0531(9)$ & $-0.0001(9)$ & $-0.0168(8)$ & $0.0011(8)$ \\
$\mathrm{C} 2$ & $0.0722(11)$ & $0.0804(12)$ & $0.0567(10)$ & $-0.0046(9)$ & $-0.0130(8)$ & $-0.0101(9)$ \\
$\mathrm{C} 3$ & $0.0471(8)$ & $0.0699(11)$ & $0.0689(10)$ & $-0.0042(8)$ & $-0.0036(8)$ & $-0.0074(9)$ \\
$\mathrm{C} 4$ & $0.0517(8)$ & $0.0632(9)$ & $0.0548(8)$ & $-0.0022(7)$ & $-0.0015(7)$ & $0.0025(7)$ \\
$\mathrm{C} 5$ & $0.0431(7)$ & $0.0651(9)$ & $0.0443(8)$ & $-0.0003(6)$ & $0.0012(6)$ & $0.0006(7)$ \\
$\mathrm{C} 6$ & $0.0403(7)$ & $0.0641(9)$ & $0.0407(7)$ & $0.0037(6)$ & $-0.0012(5)$ & $0.0012(6)$ \\
$\mathrm{C} 7$ & $0.0500(8)$ & $0.0644(9)$ & $0.0405(7)$ & $0.0018(7)$ & $0.0005(6)$ & $0.0004(6)$ \\
C8 & $0.0438(7)$ & $0.0622(8)$ & $0.0415(7)$ & $0.0039(6)$ & $0.0034(6)$ & $0.0000(6)$ \\
C9 & $0.0485(8)$ & $0.0647(9)$ & $0.0406(7)$ & $0.0083(7)$ & $-0.0011(6)$ & $0.0022(6)$ \\
C10 & $0.0706(11)$ & $0.0699(10)$ & $0.0458(8)$ & $-0.0005(9)$ & $-0.0104(8)$ & $0.0001(7)$ \\
C11 & $0.0635(10)$ & $0.0775(11)$ & $0.0535(9)$ & $-0.0047(8)$ & $-0.0080(8)$ & $-0.0071(8)$ \\
C12 & $0.0598(9)$ & $0.0662(10)$ & $0.0600(9)$ & $-0.0047(8)$ & $0.0047(8)$ & $-0.0057(8)$ \\
C13 & $0.0581(9)$ & $0.0640(9)$ & $0.0515(8)$ & $0.0032(7)$ & $0.0038(7)$ & $0.0035(7)$ \\
C14 & $0.0715(12)$ & $0.0732(12)$ & $0.0892(15)$ & $-0.0048(10)$ & $-0.0069(10)$ & $-0.0125(11)$ \\
C15 & $0.1057(17)$ & $0.0729(13)$ & $0.0830(14)$ & $-0.0185(12)$ & $-0.0037(13)$ & $-0.0044(11)$ \\
C16 & $0.0535(9)$ & $0.0854(12)$ & $0.0676(10)$ & $0.0171(9)$ & $-0.0066(8)$ & $-0.0088(9)$ \\
C17 & $0.0826(12)$ & $0.0698(10)$ & $0.0454(8)$ & $0.0057(9)$ & $-0.0007(8)$ & $0.0085(7)$ \\
C18 & $0.0699(10)$ & $0.0729(10)$ & $0.0415(8)$ & $-0.0074(8)$ & $0.0004(7)$ & $0.0087(7)$ \\
C19 & $0.0803(13)$ & $0.0706(10)$ & $0.0429(8)$ & $-0.0053(9)$ & $-0.0014(8)$ & $0.0107(7)$ \\
C20 & $0.0827(15)$ & $0.0995(15)$ & $0.0682(13)$ & $0.0113(12)$ & $-0.0027(11)$ & $0.0173(12)$ \\
& & & & & & \\
\hline
\end{tabular}

Geometric parameters $\left(\AA,{ }^{\circ}\right)$

\begin{tabular}{llll}
\hline $\mathrm{N} 1-\mathrm{C} 7$ & $1.391(2)$ & $\mathrm{C} 9-\mathrm{C} 17$ & $1.542(2)$ \\
$\mathrm{N} 1-\mathrm{C} 18$ & $1.465(2)$ & $\mathrm{C} 10-\mathrm{C} 11$ & $1.381(3)$ \\
$\mathrm{N} 1-\mathrm{C} 5$ & $1.467(2)$ & $\mathrm{C} 10-\mathrm{H} 10$ & 0.9300 \\
$\mathrm{C} 1-\mathrm{C} 2$ & $1.514(3)$ & $\mathrm{C} 11-\mathrm{C} 12$ & $1.381(3)$ \\
$\mathrm{C} 1-\mathrm{C} 6$ & $1.533(2)$ & $\mathrm{C} 11-\mathrm{H} 11$ & 0.9300 \\
$\mathrm{C} 1-\mathrm{H} 1 \mathrm{~A}$ & 0.9700 & $\mathrm{C} 12-\mathrm{C} 13$ & $1.388(3)$ \\
$\mathrm{C} 1-\mathrm{H} 1 \mathrm{~B}$ & 0.9700 & $\mathrm{C} 12-\mathrm{C} 15$ & $1.512(3)$ \\
$\mathrm{C} 2-\mathrm{C} 3$ & $1.511(3)$ & $\mathrm{C} 13-\mathrm{H} 13$ & 0.9300 \\
$\mathrm{C} 2-\mathrm{H} 2 \mathrm{~A}$ & 0.9700 & $\mathrm{C} 14-\mathrm{H} 14 \mathrm{~A}$ & 0.9600 \\
$\mathrm{C} 2-\mathrm{H} 2 \mathrm{~B}$ & 0.9700 & $\mathrm{C} 14-\mathrm{H} 14 \mathrm{~B}$ & 0.9600 \\
$\mathrm{C} 3-\mathrm{C} 14$ & $1.517(3)$ & $\mathrm{C} 14-\mathrm{H} 14 \mathrm{C}$ & 0.9600 \\
$\mathrm{C} 3-\mathrm{C} 4$ & $1.525(2)$ & $\mathrm{C} 15-\mathrm{H} 15 \mathrm{~A}$ & 0.9600 \\
$\mathrm{C} 3-\mathrm{H} 3$ & 0.9800 & $\mathrm{C} 15-\mathrm{H} 15 \mathrm{~B}$ & 0.9600 \\
$\mathrm{C} 4-\mathrm{C} 5$ & $1.530(2)$ & $\mathrm{C} 15-\mathrm{H} 15 \mathrm{C}$ & 0.9600 \\
$\mathrm{C} 4-\mathrm{H} 4 \mathrm{~A}$ & 0.9700 & $\mathrm{C} 16-\mathrm{H} 16 \mathrm{~A}$ & 0.9600 \\
$\mathrm{C} 4-\mathrm{H} 4 \mathrm{~B}$ & 0.9700 & $\mathrm{C} 16-\mathrm{H} 16 \mathrm{~B}$ & 0.9600 \\
$\mathrm{C} 5-\mathrm{C} 6$ & $1.532(2)$ & $\mathrm{C} 16-\mathrm{H} 16 \mathrm{C}$ & 0.9600 \\
$\mathrm{C} 5-\mathrm{H} 5$ & 0.9800 & $\mathrm{C} 17-\mathrm{H} 17 \mathrm{~A}$ & 0.9600 \\
$\mathrm{C} 6-\mathrm{C} 9$ & $1.550(2)$ & $\mathrm{C} 17-\mathrm{H} 17 \mathrm{~B}$ & 0.9600 \\
$\mathrm{C} 6-\mathrm{H} 6$ & 0.9800 & $\mathrm{C} 17-\mathrm{H} 17 \mathrm{C}$ & 0.9600 \\
$\mathrm{C} 7-\mathrm{C} 10$ & $1.404(2)$ & $\mathrm{C} 18-\mathrm{C} 19$ & $1.469(3)$
\end{tabular}




\begin{tabular}{|c|c|c|c|}
\hline $\mathrm{C} 7-\mathrm{C} 8$ & $1.407(2)$ & $\mathrm{C} 18-\mathrm{H} 18 \mathrm{~A}$ & 0.9700 \\
\hline $\mathrm{C} 8-\mathrm{C} 13$ & $1.392(2)$ & $\mathrm{C} 18-\mathrm{H} 18 \mathrm{~B}$ & 0.9700 \\
\hline $\mathrm{C} 8-\mathrm{C} 9$ & $1.528(2)$ & $\mathrm{C} 19-\mathrm{C} 20$ & $1.168(3)$ \\
\hline $\mathrm{C} 9-\mathrm{C} 16$ & $1.539(2)$ & $\mathrm{C} 20-\mathrm{H} 20$ & 0.9300 \\
\hline $\mathrm{C} 7-\mathrm{N} 1-\mathrm{C} 18$ & $117.18(14)$ & $\mathrm{C} 8-\mathrm{C} 9-\mathrm{C} 6$ & $108.94(13)$ \\
\hline $\mathrm{C} 7-\mathrm{N} 1-\mathrm{C} 5$ & $121.04(13)$ & $\mathrm{C} 16-\mathrm{C} 9-\mathrm{C} 6$ & $112.13(14)$ \\
\hline $\mathrm{C} 18-\mathrm{N} 1-\mathrm{C} 5$ & $117.14(14)$ & $\mathrm{C} 17-\mathrm{C} 9-\mathrm{C} 6$ & $108.53(13)$ \\
\hline $\mathrm{C} 2-\mathrm{C} 1-\mathrm{C} 6$ & $112.89(15)$ & $\mathrm{C} 11-\mathrm{C} 10-\mathrm{C} 7$ & $121.85(16)$ \\
\hline $\mathrm{C} 2-\mathrm{C} 1-\mathrm{H} 1 \mathrm{~A}$ & 109.0 & $\mathrm{C} 11-\mathrm{C} 10-\mathrm{H} 10$ & 119.1 \\
\hline $\mathrm{C} 6-\mathrm{C} 1-\mathrm{H} 1 \mathrm{~A}$ & 109.0 & $\mathrm{C} 7-\mathrm{C} 10-\mathrm{H} 10$ & 119.1 \\
\hline $\mathrm{C} 2-\mathrm{C} 1-\mathrm{H} 1 \mathrm{~B}$ & 109.0 & $\mathrm{C} 10-\mathrm{C} 11-\mathrm{C} 12$ & $121.23(17)$ \\
\hline $\mathrm{C} 6-\mathrm{C} 1-\mathrm{H} 1 \mathrm{~B}$ & 109.0 & $\mathrm{C} 10-\mathrm{C} 11-\mathrm{H} 11$ & 119.4 \\
\hline $\mathrm{H} 1 \mathrm{~A}-\mathrm{C} 1-\mathrm{H} 1 \mathrm{~B}$ & 107.8 & $\mathrm{C} 12-\mathrm{C} 11-\mathrm{H} 11$ & 119.4 \\
\hline $\mathrm{C} 3-\mathrm{C} 2-\mathrm{C} 1$ & $111.02(17)$ & $\mathrm{C} 11-\mathrm{C} 12-\mathrm{C} 13$ & $116.75(17)$ \\
\hline $\mathrm{C} 3-\mathrm{C} 2-\mathrm{H} 2 \mathrm{~A}$ & 109.4 & $\mathrm{C} 11-\mathrm{C} 12-\mathrm{C} 15$ & $121.55(18)$ \\
\hline $\mathrm{C} 1-\mathrm{C} 2-\mathrm{H} 2 \mathrm{~A}$ & 109.4 & $\mathrm{C} 13-\mathrm{C} 12-\mathrm{C} 15$ & $121.69(18)$ \\
\hline $\mathrm{C} 3-\mathrm{C} 2-\mathrm{H} 2 \mathrm{~B}$ & 109.4 & $\mathrm{C} 12-\mathrm{C} 13-\mathrm{C} 8$ & $124.06(16)$ \\
\hline $\mathrm{C} 1-\mathrm{C} 2-\mathrm{H} 2 \mathrm{~B}$ & 109.4 & $\mathrm{C} 12-\mathrm{C} 13-\mathrm{H} 13$ & 118.0 \\
\hline $\mathrm{H} 2 \mathrm{~A}-\mathrm{C} 2-\mathrm{H} 2 \mathrm{~B}$ & 108.0 & $\mathrm{C} 8-\mathrm{C} 13-\mathrm{H} 13$ & 118.0 \\
\hline $\mathrm{C} 2-\mathrm{C} 3-\mathrm{C} 14$ & $112.77(19)$ & $\mathrm{C} 3-\mathrm{C} 14-\mathrm{H} 14 \mathrm{~A}$ & 109.5 \\
\hline $\mathrm{C} 2-\mathrm{C} 3-\mathrm{C} 4$ & $109.82(15)$ & $\mathrm{C} 3-\mathrm{C} 14-\mathrm{H} 14 \mathrm{~B}$ & 109.5 \\
\hline $\mathrm{C} 14-\mathrm{C} 3-\mathrm{C} 4$ & $111.95(16)$ & $\mathrm{H} 14 \mathrm{~A}-\mathrm{C} 14-\mathrm{H} 14 \mathrm{~B}$ & 109.5 \\
\hline $\mathrm{C} 2-\mathrm{C} 3-\mathrm{H} 3$ & 107.3 & $\mathrm{C} 3-\mathrm{C} 14-\mathrm{H} 14 \mathrm{C}$ & 109.5 \\
\hline $\mathrm{C} 14-\mathrm{C} 3-\mathrm{H} 3$ & 107.3 & $\mathrm{H} 14 \mathrm{~A}-\mathrm{C} 14-\mathrm{H} 14 \mathrm{C}$ & 109.5 \\
\hline $\mathrm{C} 4-\mathrm{C} 3-\mathrm{H} 3$ & 107.3 & $\mathrm{H} 14 \mathrm{~B}-\mathrm{C} 14-\mathrm{H} 14 \mathrm{C}$ & 109.5 \\
\hline $\mathrm{C} 3-\mathrm{C} 4-\mathrm{C} 5$ & $113.42(14)$ & $\mathrm{C} 12-\mathrm{C} 15-\mathrm{H} 15 \mathrm{~A}$ & 109.5 \\
\hline $\mathrm{C} 3-\mathrm{C} 4-\mathrm{H} 4 \mathrm{~A}$ & 108.9 & $\mathrm{C} 12-\mathrm{C} 15-\mathrm{H} 15 \mathrm{~B}$ & 109.5 \\
\hline $\mathrm{C} 5-\mathrm{C} 4-\mathrm{H} 4 \mathrm{~A}$ & 108.9 & $\mathrm{H} 15 \mathrm{~A}-\mathrm{C} 15-\mathrm{H} 15 \mathrm{~B}$ & 109.5 \\
\hline $\mathrm{C} 3-\mathrm{C} 4-\mathrm{H} 4 \mathrm{~B}$ & 108.9 & $\mathrm{C} 12-\mathrm{C} 15-\mathrm{H} 15 \mathrm{C}$ & 109.5 \\
\hline $\mathrm{C} 5-\mathrm{C} 4-\mathrm{H} 4 \mathrm{~B}$ & 108.9 & $\mathrm{H} 15 \mathrm{~A}-\mathrm{C} 15-\mathrm{H} 15 \mathrm{C}$ & 109.5 \\
\hline $\mathrm{H} 4 \mathrm{~A}-\mathrm{C} 4-\mathrm{H} 4 \mathrm{~B}$ & 107.7 & $\mathrm{H} 15 \mathrm{~B}-\mathrm{C} 15-\mathrm{H} 15 \mathrm{C}$ & 109.5 \\
\hline $\mathrm{N} 1-\mathrm{C} 5-\mathrm{C} 4$ & $110.99(13)$ & $\mathrm{C} 9-\mathrm{C} 16-\mathrm{H} 16 \mathrm{~A}$ & 109.5 \\
\hline $\mathrm{N} 1-\mathrm{C} 5-\mathrm{C} 6$ & $110.04(13)$ & $\mathrm{C} 9-\mathrm{C} 16-\mathrm{H} 16 \mathrm{~B}$ & 109.5 \\
\hline $\mathrm{C} 4-\mathrm{C} 5-\mathrm{C} 6$ & $109.98(13)$ & $\mathrm{H} 16 \mathrm{~A}-\mathrm{C} 16-\mathrm{H} 16 \mathrm{~B}$ & 109.5 \\
\hline $\mathrm{N} 1-\mathrm{C} 5-\mathrm{H} 5$ & 108.6 & $\mathrm{C} 9-\mathrm{C} 16-\mathrm{H} 16 \mathrm{C}$ & 109.5 \\
\hline $\mathrm{C} 4-\mathrm{C} 5-\mathrm{H} 5$ & 108.6 & $\mathrm{H} 16 \mathrm{~A}-\mathrm{C} 16-\mathrm{H} 16 \mathrm{C}$ & 109.5 \\
\hline $\mathrm{C} 6-\mathrm{C} 5-\mathrm{H} 5$ & 108.6 & $\mathrm{H} 16 \mathrm{~B}-\mathrm{C} 16-\mathrm{H} 16 \mathrm{C}$ & 109.5 \\
\hline $\mathrm{C} 5-\mathrm{C} 6-\mathrm{C} 1$ & $109.31(14)$ & $\mathrm{C} 9-\mathrm{C} 17-\mathrm{H} 17 \mathrm{~A}$ & 109.5 \\
\hline $\mathrm{C} 5-\mathrm{C} 6-\mathrm{C} 9$ & $113.23(13)$ & $\mathrm{C} 9-\mathrm{C} 17-\mathrm{H} 17 \mathrm{~B}$ & 109.5 \\
\hline $\mathrm{C} 1-\mathrm{C} 6-\mathrm{C} 9$ & $113.91(13)$ & $\mathrm{H} 17 \mathrm{~A}-\mathrm{C} 17-\mathrm{H} 17 \mathrm{~B}$ & 109.5 \\
\hline $\mathrm{C} 5-\mathrm{C} 6-\mathrm{H} 6$ & 106.6 & $\mathrm{C} 9-\mathrm{C} 17-\mathrm{H} 17 \mathrm{C}$ & 109.5 \\
\hline $\mathrm{C} 1-\mathrm{C} 6-\mathrm{H} 6$ & 106.6 & $\mathrm{H} 17 \mathrm{~A}-\mathrm{C} 17-\mathrm{H} 17 \mathrm{C}$ & 109.5 \\
\hline $\mathrm{C} 9-\mathrm{C} 6-\mathrm{H} 6$ & 106.6 & $\mathrm{H} 17 \mathrm{~B}-\mathrm{C} 17-\mathrm{H} 17 \mathrm{C}$ & 109.5 \\
\hline $\mathrm{N} 1-\mathrm{C} 7-\mathrm{C} 10$ & $120.02(14)$ & $\mathrm{N} 1-\mathrm{C} 18-\mathrm{C} 19$ & $112.97(15)$ \\
\hline $\mathrm{N} 1-\mathrm{C} 7-\mathrm{C} 8$ & $122.17(14)$ & $\mathrm{N} 1-\mathrm{C} 18-\mathrm{H} 18 \mathrm{~A}$ & 109.0 \\
\hline $\mathrm{C} 10-\mathrm{C} 7-\mathrm{C} 8$ & $117.80(15)$ & $\mathrm{C} 19-\mathrm{C} 18-\mathrm{H} 18 \mathrm{~A}$ & 109.0 \\
\hline $\mathrm{C} 13-\mathrm{C} 8-\mathrm{C} 7$ & $118.29(15)$ & $\mathrm{N} 1-\mathrm{C} 18-\mathrm{H} 18 \mathrm{~B}$ & 109.0 \\
\hline
\end{tabular}




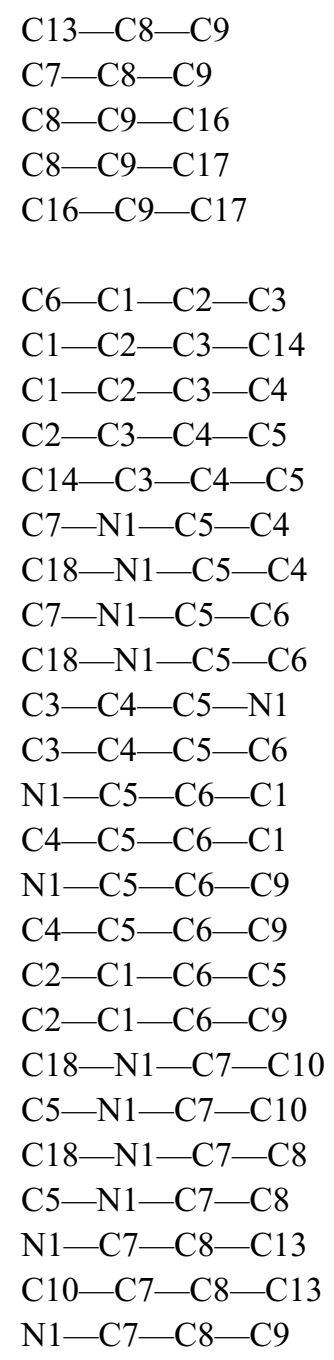

$120.52(14)$

$121.15(15)$

$108.30(13)$

$110.19(14)$

$108.76(15)$

$-57.2(2)$

$-179.78(16)$

$54.6(2)$

$-55.6(2)$

$178.33(16)$

$-155.23(15)$

$49.6(2)$

$-33.3(2)$

$171.56(14)$

$178.18(14)$

$56.18(18)$

$-177.26(14)$

$-54.69(17)$

$54.59(17)$

$177.16(12)$

$56.8(2)$

$-175.44(15)$

$-18.0(2)$

$-173.17(15)$

$162.92(16)$

$7.7(2)$

$180.00(15)$

0.9 (2)

$-2.5(2)$

$$
\begin{aligned}
& \text { C19-C18-H18B } \\
& \text { H18A-C18-H18B } \\
& \text { C20-C19-C18 } \\
& \text { C19-C20-H20 }
\end{aligned}
$$

$\mathrm{C} 10-\mathrm{C} 7-\mathrm{C} 8-\mathrm{C} 9$

$\mathrm{C} 13-\mathrm{C} 8-\mathrm{C} 9-\mathrm{C} 16$

$\mathrm{C} 7-\mathrm{C} 8-\mathrm{C} 9-\mathrm{C} 16$

$\mathrm{C} 13-\mathrm{C} 8-\mathrm{C} 9-\mathrm{C} 17$

$\mathrm{C} 7-\mathrm{C} 8-\mathrm{C} 9-\mathrm{C} 17$

$\mathrm{C} 13-\mathrm{C} 8-\mathrm{C} 9-\mathrm{C} 6$

$\mathrm{C} 7-\mathrm{C} 8-\mathrm{C} 9-\mathrm{C} 6$

$\mathrm{C} 5-\mathrm{C} 6-\mathrm{C} 9-\mathrm{C} 8$

$\mathrm{C} 1-\mathrm{C} 6-\mathrm{C} 9-\mathrm{C} 8$

$\mathrm{C} 5-\mathrm{C} 6-\mathrm{C} 9-\mathrm{C} 16$

$\mathrm{C} 1-\mathrm{C} 6-\mathrm{C} 9-\mathrm{C} 16$

$\mathrm{C} 5-\mathrm{C} 6-\mathrm{C} 9-\mathrm{C} 17$

$\mathrm{C} 1-\mathrm{C} 6-\mathrm{C} 9-\mathrm{C} 17$

$\mathrm{N} 1-\mathrm{C} 7-\mathrm{C} 10-\mathrm{C} 11$

$\mathrm{C} 8-\mathrm{C} 7-\mathrm{C} 10-\mathrm{C} 11$

$\mathrm{C} 7-\mathrm{C} 10-\mathrm{C} 11-\mathrm{C} 12$

$\mathrm{C} 10-\mathrm{C} 11-\mathrm{C} 12-\mathrm{C} 13$

$\mathrm{C} 10-\mathrm{C} 11-\mathrm{C} 12-\mathrm{C} 15$

$\mathrm{C} 11-\mathrm{C} 12-\mathrm{C} 13-\mathrm{C} 8$

$\mathrm{C} 15-\mathrm{C} 12-\mathrm{C} 13-\mathrm{C} 8$

$\mathrm{C} 7-\mathrm{C} 8-\mathrm{C} 13-\mathrm{C} 12$

C9- 8 - $\mathrm{C} 13-\mathrm{C} 12$

C7-N1-C18-C19

C5-N1-C18-C19
109.0

107.8

178.9 (2)

180.0

$178.42(14)$

78.32 (19)

$-99.15(18)$

-40.5 (2)

$142.00(16)$

$-159.48(14)$

23.05 (19)

-48.98 (16)

$-174.71(13)$

70.87 (17)

$-54.85(19)$

$-168.97(13)$

$65.30(18)$

$179.08(18)$

$-1.8(3)$

$1.3(3)$

0.1 (3)

$-178.6(2)$

$-1.0(3)$

$177.72(19)$

0.5 (3)

$-177.06(15)$

86.5 (2)

$-117.36(18)$ 